\title{
FORMATISASI ONTOLOGI MANAJEMEN DAKWAH
}

\author{
Fahriansyah \\ UIN Antasari Banjarmasin
}

\begin{abstract}
When viewed in terms of elements of da'wah combined with the ontology of general management, the study area of da'wah management as a whole is 80 format. And when viewed in terms of the combination of da'wah interaction with the ontology of general management, then obtained 96 formulation format, so that the total format of ontology of da'wah management is 176 formulations ontology format.
\end{abstract}

Keywords: da'I (interpreter), mawdhu '(message), uslub (method), wasilah (media) and mad'u (target)

\section{Pendahuluan}

Suatu ilmu jika menjadi suatu disiplin yang sistematis, rasional, empiris, umum dan kumulatif oleh kalangan ilmuwan haruslah berkategori pada tiga subtansi filsafat ilmu : ontologi, epistemologi dan aksiologi.

Istilah ontologi digunakan ketika membahas dalam konteks filsafat ilmu, atau dengan perkataan lain apakah yang dalam konteks filsafat ilmu, atau dengan perkataan lain apakah yang menjadi telaah bidang ilmu, epistemologi; bertujuan membahas tentang terjadinya dan keshahihan atau kebenaran suatu ilmu, dan aksiologi berkenaan tentang apakah kegunaan suatu ilmu.

Pada tulisan yang penulis sajikan mengenai manajemen dakwah mencoba membahas tentang ontologinya: yakni apakah yang menjadi telaah manajemen dakwah, apakah sama dengan ontologi manajemen umum ataukah berbeda, namun secara reflektif dinyatakan bahwa ontologi manajemen dakwah adalah ontologi manajemen umum ditambah dengan ciri-ciri khas tertentu yang melekat pada dakwah.

$$
\begin{array}{ll}
\text { O.M.D } & =\text { O .M .D } \\
\text { O .M.D } & =\text { Ontologi Manajemen Dakwah } \\
\text { O.M.U } & =\text { Ontologi Manajemen Umum } \\
\text { X } & =\text { Ciri Khas Dakwah }
\end{array}
$$

\section{Pembahasan}

\section{Produk Teori Dakwah}

Dakwah Islamiyah yang merupakan bentuk realisasi aktivitas untuk mengamalkan ajaran Islam memiliki tiga usaha memproduk teori-teori dakwah yakni :

1. Memahami, menalarkan dan menjelaskan hakekat dakwah bersumberkan pada AlQur'an dan al Hadits yang dikenal sebagai istinbath.

Bentuk pertama memproduk teori dakwah istinbath; yakni mengambil AlQur'an dan al Hadits sebagai sumber-sumber teori dakwah, melalui proses memahami, menalarkan dan menjelaskan hakekat dakwah maka diketahuilah apa sebenarnya dakwah menurut Al-Qur'an dan Hadits.

2. Memahami, menalarkan dan menjelaskan hakekat dakwah dengan mengkombinasikan ilmu-ilmu sosial (iqtibas). 
Bentuk kedua memproduk teori dakwah dengan cara kombinasi ilmu-ilmu sosial :

psikologi, komunikasi, sosiologi, antropologi dan lainnya dengan hakekat dakwah yang dihasilkan dari teori hasil istinbath.

3. Memahami, menalarkan dan menjelaskan hakekat dakwah melalui cara melihat hasil penelitian (istiqra).

Bentuk ketiga adalah memahami, menalarkan dan menjelaskan hakekat dakwah setelah mendapatkan masukan-masukan dari hasil penelitian, baik penelitian kualitatif maupun kuantitatif.

Sebagaimana dimaklumi penelitian adalah suatu proses dari: konseptualisasi, mengumpulkan data, membuat analisa kemudian sintesa selanjutnya dikembangkan suatu teori. Proses demikian berarti memungkinkan untuk menghasilkan produk teori melalui hasil penelitian yang kemudian disesuaikan dengan Al-Qur'an dan Hadits.

Dari usaha memproduk teori dakwah berbentuk iqtibas dan istiqra dalam kalangan pemikir islam sebagai mengenai manajemen terdapat beberapa pola pemikiran, yakni :

(1) Pemikiran Similarisasi

Similarisasi adalah menyamakan begitu saja konsep manajemen umum dengan ajaran islam sehingga dijadikan sebagai konsep manajemen dakwah, seperti rasa konsisten manajer dengan nafs al-muthmainah, penyelewengan oleh seseorang manajer dengan nafs al-ammarah.

(2) Pemikiran Paralelisasi

Konsep pemikiran paralelisasi dalam manajemen dakwah adalah menganggap sejalan (paral) konsep-konsep dari manajemen umum dengan konsep yang berasal dari Al-Qur'an dan Hadits karena adanya kemiripan konotasi, tetapi hal tersebut tidaklah melakukan penyamaan keduanya. Misalnya saling bekerjasama diparalelkan dengan Amar ma'ruf.

(3) Pemikiran Komparasi

Pemikiran Komparasi dalam manajemen dakwah adalah membandingkan konsep/teori manajemen umum dengan konsep ajaran islam mengenai gejala-gejala yang sama, seperti prinsip controlling dibanding dengan prinsip amar ma'ruf nahi munkar.

(4) Pemikiran Induktivikasi

Pemikiran Induktivikasi didasarkan pada asumsi dasar dari teori-teori ilmiah yang didukung oleh temuan-temuan empiris, dilanjutkan pemikian secara teoritisabstrak ke arah pemikian metafisika yang kemudian dihubungkan dengan prinsip ajaran islam, misalnya keteraturan alam semesta merupakan suatu manajemen yang baik dari kekuasaan Allah SWT.

(5) Pemikiran Komplementasi

Pemikiran Komplementasi yaitu antara prinsip manajemen umum dengan ajaran islam saling mengisi dan memperkuat satu sama lain tetapi tetap mempertahankan eksistensi masing-masing, contohnya : konsep-konsep perencanaan dalam manajemen umum didukung oleh ayat Al-Qur'an surat Al-Hasyr ayat 18 yang menghendaki setiap Muslim harus merencanakan apa yang akan ia lakukan untuk esok hari.

(6) Pemikiran Verifikasi

Pemikiran yang bersifat verifikasi merupakan suatu bentuk mengungkapkan hasil-hasil penelitian ilmiah dalam manajemen umum yang menunjang dan 
membuktikan kebenaran ajaran islam, contohnya : penelitian tentang penerapan, penggunaan prinsip-prinsip manajemen yang teratur dan ternyata hal tersebut ada keserasian dengan apa yang digambarkan oleh Allah SWT dalam surat Al-Nahl tentang kehidupan lebah.

\section{Wilayah Kajian Manajemen Dakwah}

Untuk memformat secara reflektif-referensial mengenai wilayah kajian manajemen dakwah, maka ada beberapa kajian urgen yang harus dilakukan yakni ontologi manajemen umum dengan unsur-unsur dakwah dan interaksi dakwah. Dari ketiga hal tersebut dapat dimulai memformat ontologi manajemen dakwah :

a. Ontologi Manajemen Umum

Ontologi Manajemen Umum adalah suatu hal penting untuk diketahui lebih awal sebelum memprediksi ontologi manajemen dakwah, karena ontologi manajemen umum ditambah dengan ciri-ciri khas tertentu pada dakwah islamiyah sendiri.

Apakah yang hendak diteliti atau obyek keilmuan manajemen umum ?, untuk mengemukakannya tentu banyak pendapat ahli manajemen yang mengemukakannya, tetapi supaya pemufakatan umum dari ahli manajemen ada baiknya mengutip pendapat tokoh monumental dari disiplin ilmu manajemen dan sering kali disebut bapak manajemen, yaitu G .R. Terry dalam buku "Principles of Management" yang menyatakan ontologi manajemen umum dalam empat kategori : Planning, Organizing, Actuating dan Controlling (perencanaan, Pengorganisasian, Penggerakan dan Pengawasan) disingkat POAC.

Perencanaan (planning) adalah : “ ...... Menentukan terlebih dahulu apa yang harus dilakukan, bagaimana cara melakukannya dan siapa yang melaksanakan semua kegiatan" (Kartini Kartono : 1974 : 79). Planning (perencanaan) berarti pemikiran yang cermat untuk mempertimbangkan, menemukan, dan mengatur faktor-faktor yang dibutuhkan dalam menjalankan sesuatu kerja (Ismail Masya, et.al: 1980: 50).

Organizing artinya mengelompokkan kegiatan dan tugas-tugas yang dimaksudkan untuk mencapai tujuan (Sofyan Syafri Harahap: 1996: 55). Pengorganisasian itu menjalin relasi diantara segenap aktivitas kerja, penggunaan tenaga manusia dan pemanfaatan semua faktor fisik (Kartini Kartono: 1994: 81).

Penggerakan adalah membuat semua anggota kelompok agar mau bekerjasama dan bekerja secara ikhlas serta bergairah untuk mencapai tujuan sesuai dengan perencanaan dan usaha-usaha pengorganisasian (Malayu: 1984: 176), sedangkan pengawasan sebagai proses penentuan apa yang harus dicapai; standar apa yang sedang dilakukan yaitu : pelakasanaan, menilai atau perbaikan, sehingga pelaksanaan sesuai rencana.

b. Unsur-unsur Dakwah

Berbagai ahli ilmu dakwah mengemukakan bahwasanya unsur-unsur Dakwah Islamiyah ada lima, yaitu :

1. Pendakwah (Da'i) adalah pelaku (subyek) utama di dalam aktivitas dakwah.

2. Pesan (mawdhu) : berkenaan dengan pesan-pesan yang disampaikan yaitu ajaran islam. 
3. Metode Dakwah : yakni cara-cara menyampaikan ajaran islam.

4. Media Dakwah : yakni berkenaan dengan sarana-sarana dalam melaksanakan dakwah.

5. Sasaran Dakwah : yakni berkenaan dengan obyek-obyek yang menjadi sasaran pelaksanaan dakwah.

c. Interaksi Dakwah

Dakwah islamiyah sebagai usaha memanggil, mengajak manusia ke jalan Allah dalam pelaksanaannya berasaskan rasional (al-'aqliyah), mempunyai kebebasan (al-Hurriyah) maupun perjuangan (al-Jihad) dalam operasionalnya mempunyai berbagai interaksi sehingga memunculkan beragam bentuk Dakwah Islamiyah.

Pertama, interaksi pendakwah dengan dirinya sendiri, dimana prinsip interaksi pertama adalah bahwa pendakwah sebelum menyampaikan ajaran islam kepada orang lain haruslah terlebih dahulu mengamalkan ajaran islam itu dalam perilaku kehidupannya sehari-hari, wujud interaksi demikian disebut Dakwah Nafsiyah.

Kedua, interaksi antara pendakwah individual dengan sasaran secara individual, tekanan interaksi demikian dalam istilah komunikasi antarpribadi disebut face to face meeting dimana pendakwah berperan sebagai pembimbing sedangkan mad'u sebagai clien (terbimbing). Ciri khas interaksi kedua adalah bahwa hubungan personal lebih banyak tekanannya, karenanya interaksi demikian adalah Dakwah Fardiyah.

Ketiga, interaksi pendakwah secara individual dengan sasarannya secara kelompok kecil yang tidak terorganisir secara sistematik, misalnya : pendakwah yang menyampaikan ajaran islam kepada sekolompok manusia yang berjumlah 2-5 orang tanpa ada organisasi yang baik (sekelompok pedagang sayur, tukang ojek dipinggir jalan), dakwah demikian disebut Dakwah Fi'ah Qaliyah.

Keempat, interaksi pendakwah secara individual dengan jumlah sasaran kelompok besar serta terorganisir, misal : pendakwah pengajian, interaksi yang demikian disebut Dakwah Hizbiyah.

Kelima, interaksi pendakwah secara individual dengan massa baik tatap muka, tidak bertatap muka namun sifatnya monologis disebut Dakwah Ummah. Dan keenam interaksi da'I individual dengan kontek berbeda suku, budaya disebut Dakwah Syu'ubiyyah.

Ketiga hal tersebut (ontologi manajemen umum, unsur-unsur dakwah dan interaksi wilayah) jika dikombinasikan akan menghasilkan format ontologi manajemen dakwah yang merupakan kajian-kajian makro untuk bisa dikembangkan secara spesifikasi sesuai dengan keadaan dan dinamikanya. Adapun format ontologi manajemen dakwah adalah :

\section{Wilayah kajian manajemen dakwah hasil kombinasi wilayah kajian manajemen umum dengan unsur-unsur dakwah.}

Unsur-unsur dakwah dalam teorinya terdiri dari da'i, pesan (mawdhu'), metode (uslub), media (wasilah) dan sasarannya (mad'u), jika unsur-unsur dakwah dikombinasikan dengan ontologi manajemen umum maka wilayah kajian manajemen dakwah adalah : 5 x $4=20$ kombinasi. 
Jika da'i $\left(\mathrm{U}_{1}\right)$, pesan $\left(\mathrm{U}_{2}\right)$, metode $\left(\mathrm{U}_{3}\right)$, media $\left(\mathrm{U}_{4}\right)$ dan sasarannya ( $\left.\mathrm{U}_{5}\right)$, sedangakan perencanaan $\left(A_{1}\right)$, Pengorganisasian $\left(A_{2}\right)$, Penggerakan $\left(A_{3}\right)$ dan Pengawasan $\left(\mathrm{A}_{4}\right)$, maka kombinasi tersebut adalah :

\begin{tabular}{|c|c|c|c|c|c|c|}
\hline $\begin{array}{c}\text { Ontologi Unsur Dakwah } \\
\text { Manajemen Dakwah }\end{array}$ & $\mathrm{U}_{1}$ & $\mathrm{U}_{2}$ & $\mathrm{U}_{3}$ & $\mathrm{U}_{4}$ & $\mathrm{U}_{5}$ & Perspektif \\
\hline $\mathrm{A}_{1}$ & $\mathrm{X}_{1}$ & $\mathrm{X}_{2}$ & $\mathrm{X}_{3}$ & $\mathrm{X}_{4}$ & $\mathrm{X}_{5}$ & $\mathrm{~T}_{1}$ \\
$\mathrm{~A}_{2}$ & $\mathrm{X}_{6}$ & $\mathrm{X}_{7}$ & $\mathrm{X}_{8}$ & $\mathrm{X}_{9}$ & $\mathrm{X}_{10}$ & $\mathrm{~T}_{2}$ \\
$\mathrm{~A}_{3}$ & $\mathrm{X}_{11}$ & $\mathrm{X}_{12}$ & $\mathrm{X}_{13}$ & $\mathrm{X}_{14}$ & $\mathrm{X}_{15}$ & $\mathrm{~T}_{3}$ \\
$\mathrm{~A}_{4}$ & $\mathrm{X}_{16}$ & $\mathrm{X}_{17}$ & $\mathrm{X}_{18}$ & $\mathrm{X}_{19}$ & $\mathrm{X}_{20}$ & $\mathrm{~T}_{4}$ \\
\hline
\end{tabular}

- $\mathrm{T}_{1} \quad=$ Teori dakwah dari al Qur'an dan al Hadits

- $\mathrm{T}_{2} \quad=$ Teori dakwah dari adopsi teori ilmu sosial

- $\mathrm{T}_{3} \quad=$ Teori dakwah produk penelitian kualitatif

- $\mathrm{T}_{4} \quad=$ Teori dakwah produk penelitian kuantitatif

Secara jelasnya format tersebut adalah :

1. Perencanaan Da'i $\left(\mathrm{X}_{1}\right)$

2. Pengorganisasian Da'i $\left(\mathrm{X}_{2}\right)$---------- Unsur Da'I $\left(\mathrm{U}_{1}\right)$

3. Penggerakan Da'i $\left(\mathrm{X}_{3}\right)$

4. Pengawasan Da'i $\left(\mathrm{X}_{4}\right)$

5. Perencanaan Pesan $\left(\mathrm{X}_{5}\right)$

6. Pengorganisasian Pesan $\left(\mathrm{X}_{6}\right)$--------- Unsur Pesan $\left(\mathrm{U}_{2}\right)$

7. Penggerakan Pesan $\left(\mathrm{X}_{7}\right)$

8. Penggerakan Pesan $\left(\mathrm{X}_{8}\right)$

9. Perencanaan Metode $\left(\mathrm{X}_{9}\right)$

10. Pengorganisasian Metode $\left(\mathrm{X}_{10}\right)$---------- Unsur Metode $\left(\mathrm{U}_{3}\right)$

11. Penggerakan Metode $\left(\mathrm{X}_{11}\right)$

12. Pengawasan Metode $\left(\mathrm{X}_{12}\right)$

13. Perencanaan Media $\left(\mathrm{X}_{13}\right)$

14. Pengorganisasian Media $\left(\mathrm{X}_{14}\right)$ Unsur Media $\left(\mathrm{U}_{4}\right)$

15. Penggerakan Media $\left(\mathrm{X}_{15}\right)$

16. Pengawasan Media $\left(\mathrm{X}_{16}\right)$

17. Perencanaan Sasaran $\left(X_{17}\right)$

18. Pengorganisasian Sasaran $\left(\mathrm{X}_{18}\right)$---------- Unsur Sasaran $\left(\mathrm{U}_{5}\right)$

19. Penggerakan Sasaran $\left(X_{19}\right)$

20. Pengawasan Sasaran $\left(\mathrm{X}_{20}\right)$

Jika semua format tersebut diujikan dengan perspektif teori-teori dakwah (dari produk Itinbath, Iqtibas, dan Istiqra), maka fromat ontologinya adalah : Teori dakwah dikalikan dengan format ontologi manajemen dakwah : $20 \times 4=80$ format ontologinya.

\section{Wilayah kajian manajemen dakwah kombinasi ontologi manajemen umum dengan interaksi dakwah.}

Pada bagian interaksi dakwah dikemukakan ada enam macam interaksi, yaitu Dakwah Intra Indiviual/Nafsiyah $\left(\mathrm{D}_{1}\right)$, Dakwah antar Individual/Fardiyah $\left(\mathrm{D}_{2}\right)$, Dakwah Kelompok/Fi'ah qalilah ( $\left.\mathrm{D}_{3}\right)$, Dakwah Organisasional/Hizbiyah ( $\left.\mathrm{D}_{4}\right)$, Dakwah Massa/Ummah (D5), Dakwah antar budaya, suku/Syu'ubiyah (D6). Jika keenam interaksi dakwah dikombinasikan dengan ontologi manajemen umum; Perencanaan 
$\left(A_{1}\right)$, Pengorganisasian $\left(A_{2}\right)$, Penggerakan $\left(A_{3}\right)$ dan Pengawasan $\left(A_{4}\right)$, maka akan ditemukan $=6 \times 4=24$ format ontologinya.

Perencaan $\left(\mathrm{A}_{1}\right)$

Pengorganisa-sian

$\left(\mathrm{A}_{2}\right)$

Penggerakan $\left(\mathrm{A}_{3}\right)$

Pengawasan $\left(\mathrm{A}_{4}\right)$
Dakwah Intra

Indiviual/Nafsiyah $\left(\mathrm{D}_{1}\right)$

Dakwah antar

Individual/Fardiyah $\left(\mathrm{D}_{2}\right)$

Dakwah Kleompok/Fi'ah

qalilah $\left(\mathrm{D}_{3}\right)$

Dakwah

Organisasional/Hizbiyah $\left(\mathrm{D}_{4}\right)$

Dakwah Massa/Ummah (D5)

Dakwah antar budaya,

suku/Syu'ubiyah $\left(\mathrm{D}_{6}\right)$ $\begin{array}{lr}\text { Jika } & 24 \\ \text { format } & \text { ontologi }\end{array}$ manajemen dakwah tersebut

dikombinasikandeng an perspektif teori dakwah $\left(\mathrm{T}_{1}, \mathrm{~T}_{2}, \mathrm{~T}_{3}\right.$, $\mathrm{T}_{4}$ ), maka formatnya $=24 \times 4=96$ format ontologi.

Berdasarkan pada paparan tersebut maka wilayah kajian manajemen dakwah secara keseluruhan adalah : 80 format dilihat pada aspek unsur-unsur dakwah dikombinasikan dengan ontologi manajemen umum, dan 96 format yang menyangkut kombinasi interaksi dakwah dengan ontologi manajemen umum sehingga jumlah keseluruhan format ontologi dakwah adalah 179 format ontologi.

\section{Simpulan}

Format ontologi manajemen dakwah disusun secara "reflektif intuitif referensial" guna mengemukakan pokok-pokok wilayah kajian manajemen dakwah yang nantinya bermanfaat bagi pemerhati dakwah, terutama sekali tentang manajemen dakwah, serta sebagai bahan pertimbangan bagi kajian-kajian yang memungkinkan peneliti-peneliti manajemen dakwah untuk mengembangkan penelitian dibidang manajemen dakwah.

Sebagai sebuah paparan "reflektif intuitif referensial" maka sudah tentu akan mendapatkan kritikan-kritikan terutama pada kuantitas format ontologi manajemen dakwah, tetapi perlu dipertegaskan jumlah 176 format ontologi manajemen dakwah tersebut hanyalah pokok-pokok saja, untuk pengembangannya secara mendetail dapat dilakukan dan sudah tentu jumlahnya akan terus bertambah dan berkembang sesuai perkembangan dinamika manajemen dakwah sendiri.

\section{Daftar Pustaka}

Abdul Basit, Filsafat Dakwah, PT RajaGrafindo Persada, Jakarta, 2013.

Ali Mustafa Yaqub, Sejarah dan Metode Dakwah Nabi, Pustaka Firdaus, Jakarta,1997

Achmad Mubarok, Psikologi Dakwah Membangun Cara Berpikir dan Merasa, Madani Malang, 2014.

Abdul Malik bin Ahmad Ramadhani, 6 Landasan Utama Dakwah Salafiyah, Pustaka Imam Asy Syafi'i, Jakarta, 2005.

Asep Muhyidin dan Agus Ahmad Safei, Metode Pengembangan Dakwah, Pustaka Setia, Bandung2002. 
Ali bin Hasan al Halaby al Atsry, Menggugat Keberadaan Jama'ah-Jama'ah Islam, Pustaka Al Kautsar, Jakarta, 1994.

Abdul Rosyad Shaleh, Manajemen Da'wah Islam, Bulan Bintang, Jakarta, 1977

Donnelly,et.al, Fundamentals of Management, Busines Pulication, Inc, Texas, 1984

Henry Van Lear, Filsafat Sain Ilmu Pengetahuan Secara Umum, Editot:Yudian W.Asmin, Lembaga Penterjemah dan Penulis Muslim Indonesia, Yogyakarta, 1995.

Ismail Masya, et.al, Manajemen, Dep.P \& K bagian Proyek Pengadaan Buku Sekolah

Jujun S. Suriasumantri, Ilmu Dalam Perspektif, Yayasan Obor Indonesia dan LEKNASLIPI, Jakarta, 1981.

Kartini Kartono, Psikolgi Sosial Untuk Manajemen, Perusahaan dan Industri, PT.RajaGrafindo Persada, Jakarta, 1994.

Malayu SP, Manajemen, Dasar, Pengertian dan Masalah, CV.Haji Masaagung, Jakarta, 1984.

Noeng Muhajir, Filsafat Ilmu, Telaah Sistematis, Fungsional, Komparatif, Rake Sarasin, Jogjakarta, 1998.

Sofyan Safri H, Manajemen Kontemporer, PT RajaGrafindo Persada, Jakarta, 1996.

Terry GR, Principles of Management, disadur Winardi, Alumni Bandung, 1970. 